\title{
Colonial Affairs
}

\section{PAUL S. REINSCH}

Congress has authorized the establishment of an agricultural bank in the Philippine Islands. The institution is to be modeled upon a similar bank in Egypt, which has been very successful. The regulations imposed by congress fix the maximum rate of interest at ten per cent and the maximum of loans to any one person at five thousand dollars $(\$ 5000)$. Though the bureau of insular affairs has brought this matter to the attention of American financiers, it has met with little response; but it will be comparatively easy to secure capital for the undertaking in Great Britain and other European countries.

The Indian National Congress which met in Calcutta from December 27 to 29 passed resolutions against the partition of Bengal, supporting the Swadeshi movement for home manufacturers, endorsing the Bengal boycott, calling for the separation of judicial and executive functions in the districts, advocating compulsory free education and the increase of the powers of legislative councils and municipalities. The boycott of British goods in Bengal was endorsed as being the only means by which a population which felt its political rights outraged could, under existing Indian conditions, make its opinion felt with the government. The partition of Bengal aroused so much violent feeling, because, by destroying a historic province, it increased the political importance of the Mohammedans, who constitute the majority of inhabitants of the new province of Eastern Bengal. The most notable event of the congress was the address of Mr. Naoroji in which he outlined the political demands of the Hindoo reform party.

To counterbalance the influence of the Indian National Congress, which is almost entirely Hindoo in its composition, an All-India Mohammedan Conference was held at Dacca in Eastern Bengal, contemporary with the national congress. This conference, composed of three thousand delegates, resolved to promote feelings of loyalty to the British government, to protect the political rights of the Indian Mussulmans, and to work for harmony with other communities in India. The partition of Bengal was endorsed by the conference.

The drift of the British expert opinion on the situation of Indian politics is indicated by the discussion in the East India Association on February 22. Mr. J. D. Anderson, of the Indian civil service, read a 
paper on Indian Constitutional Problems, in which he urged especially the need for further decentralization and the strengthening of the provincial legislative councils. He also favored the increase of the members of Indian officials in the higher administration, and the establishment of a training college in India, where both Britishers and natives could be prepared for the civil service. This would remove the necessity of Indians coming to England to prepare for their examinations. Lord Reay, in the discussion of the paper, dwelt on the importance of the vice-regal legislative council, and suggested that with extended powers of election, it would become essential to safeguard the rights of minorities through proportional representation.

According to two recent dispatches of Lord Elgin, Secretary of State for the colonies (Cd. 3337 and Cd. 3340), the program of the colonial conference, convened in April, consists of the following subjects: Constitution of Future Conferences, Preferential Trade, Defence, Naturalization, Emigration, Reservation of Bills, Extension of British Interests in the Pacific. If time allows, the discussions will include the questions of uniformity of patents and merchandise marks legislation, reciprocity in admission to professions, and the adoption of the metric system. Separate discussions will be arranged with the home departments chiefly interested on certain additional subjects, of which the chief are the possibility of a universal penny postage and the adoption of a decimal currency in the empire. The colonial secretary has decided that the individual Australian States are not to be given separate representation at the conference, in addition to the Australian Commonwealth. The consideration of British interests in the Pacific was suggested by the Australian government. It is to be noted that the Canadian administration is opposed to the conclusion of any general agreement for imperial defence, nor does it favor the creation of a more formal council. The subject of preferential trade arrangements seems to be the only one which Canada feels interested in; butin this matter, no further advances are to be expected of the colony unless the mother country will grant some reciprocal benefits, and unless the fiscal autonomy of Canada can be completely guarded.

The cabinet of the self-governing colony of the Transvaal, which was sworn in on March 4, is as follows:

Premier and Minister of Agriculture, General Botha; Colonial Sec- 
retary, Mr. Smuts; Attorney-General and Minister of Mines, Mr. J. de Villiers; Treasurer, Mr. Hull; Minister of Lands and Native Affairs Mr. Rissik; Minister of Public Works, Mr. E. Solomon.

The composition of the cabinet is regarded as very strong, as it contains the four most influential leaders of the Boer party. General Beyers is speaker of the assembly, and General Schalkburger a prominent member. The fact that within so short a period after the war, the leaders of the vanquished have been permitted to get political power and authority into their hands, is universally commented on as a most striking instance of the traditional liberalism of British colonial policy. General Botha will take part, as one of the colonial premiers, in the colonial conference at London. The first measure introduced by the new government is the Asiatic ordinance, which aims at the exclusion of other Indian and other Asiatic immigrants of the small trading class. This act was passed by the late legislative assembly, but was disallowed at that time by the colonial secretary. The ordinance is causing some uneasiness in India and Japan.

\section{INTERNATIONAL RELATIONS}

\section{PAUL S. REINSCH}

On January twenty-fourth, the ambassadors of France and of Italy at Constantinople sent a joint note to the Porte which announced that certain religious establishments belonging to the Dominican and Franciscan missions in Asia Minor, which had hitherto been under the French religious protectorate, would hereafter be under Italian protection. This arrangement indicates the desire of a large number of the Roman Catholic ecclesiastics working in the near East to leave the protection of France. The historic position of France as the protector of Christian missions in the Orient appears, therefore, more seriously threatened than ever before, on account of the controversy between the French government and the Vatican.

The question of patent and trade-mark protection in China has not as yet been satisfactorily settled. At present there is no Chinese law on the subject, but by mutual agreement the leading nations of Europe and the United States have arranged that their citizens shall enjoy the same protection of these rights in China which they are guaranteed by the general treaties between these powers. Japan is 